\title{
Encompassing ATP, DNA, insulin, and protein content for quantification and assessment of human pancreatic islets
}

\author{
Meirigeng Qi • Shiela Bilbao • Elena Forouhar • Fouad Kandeel • \\ Ismail H. Al-Abdullah
}

Received: 24 May 2017/ Accepted: 11 September 2017/Published online: 15 September 2017

(C) The Author(s) 2017. This article is an open access publication

\begin{abstract}
Islet transplantation has made major progress to treat patients with type 1 diabetes. Islet mass and quality are critically important to ensure successful transplantation. Currently, islet status is evaluated using insulin secretion, oxygen consumption rate, or adenosine triphosphate (ATP) measurement. These parameters are evaluated independently and do not effectively predict islet status post-transplant. Therefore, assessing human pancreatic islets by encompassing ATP, DNA, insulin, and protein content from a single tissue sample would serve as a better predictor for islet status. In this study, a single step procedure for extracting ATP, DNA, insulin, and protein content from human pancreatic islets was described and the biomolecule contents were quantified. Additionally, different mathematical calculations integrating total ATP, DNA, insulin, and protein content were randomly tested under various conditions to predict islet status. The results demonstrated that the ATP assay was efficient and the biomolecules were effectively quantified. Furthermore, the mathematical formula we developed could be optimized to predict islet status. In conclusion, our results indicate a proof-of-concept that a simple logarithmic formula can predict overall islet
\end{abstract}

M. Qi · S. Bilbao · E. Forouhar · F. Kandeel .

I. H. Al-Abdullah ( $₫)$

Department of Translational Research and Cellular

Therapeutics, Diabetes and Metabolism Research

Institute, Beckman Research Institute of City of Hope,

1500 E. Duarte Rd, Duarte, CA 91010, USA

e-mail: IAl-Abdullah@coh.org status for various conditions when total islet ATP, DNA, insulin, and protein content are simultaneously assessed from a single tissue sample.

Keywords ATP · DNA · Insulin · Protein · Human islets $\cdot$ Mathematical formula

\section{Introduction}

The pancreas is composed of endocrine and exocrine glands, which play an important role in metabolism and energy homeostasis. The endocrine gland contains the Islets of Langerhans (islets), which consist of insulin-producing $\beta$-cells, glucagon-producing $\alpha$ cells, somatostatin-producing $\delta$-cells, pancreatic polypeptide-producing PP-cells, and ghrelin-producing $\varepsilon$-cells (Bonner-Weir et al. 2015). Islet $\beta$-cells secrete insulin to regulate carbohydrate metabolism (Lacy 1967). Type 1 diabetes is an autoimmune disorder that causes destruction of $\beta$-cells (Wang et al. 2017; Kracht et al. 2017) and exogenous insulin is often required to treat the disease. However, unphysiological control of glucose homeostasis with insulin in diabetic patients leads to diabetic complications (Cox et al. 1987). Replacement of destructed $\beta$-cells by transplanting islets from human cadaveric pancreata achieves euglycemia and insulin independence in subsets of patients with type 1 diabetes (Hering et al. 2016; Ricordi et al. 2016). Thus, assessing the status of 
islets harvested from the human cadaveric pancreata prior to transplantation is critically important to ensure that the transplantation is effective in controlling patient's glucose homeostasis (Sweet et al. 2005; Papas et al. 2009).

ATP (Adenosine 5'-triphosphate) molecules, acting as a critical cellular energy source and extracellular messenger, are essential for cell metabolism, signaling pathways, and other biological activities (Zhou et al. 2009; Larsson et al. 2000; Zimmermann 2016). The current method for measuring ATP relies on highperformance liquid chromatography (HPLC) (Manfredi et al. 2002; Chida et al. 2012) and commercially available chemiluminescence kits (Shepherd et al. 2006; Phillippy 1994; Shepherd and Rinker 2004). HPLC is tedious and lengthy, and often associated with failure to quantify ATP content. The commercially available chemiluminescence kits are costly, and the reagents are inefficient to extract total ATP content. Therefore, these approaches for ATP measurement are not sensitive enough to assess islet status. Additionally, the intracellular ATP content of human islets varies largely (Brandhorst et al. 1999). This may be due to inconsistency of donor characteristics (Qi et al. 2015b) and the fact that human pancreas contains various sizes of islets in different proportions (Buchwald et al. 2016). Indeed, ADP/ATP and ATP/DNA ratios have been used to evaluate mitochondrial ATP production for predicting cell or islet condition (Goto et al. 2006; Suszynski et al. 2008). Nevertheless, ATP, DNA, insulin, and protein content of islet preparations have never been integrated into assessments of islet status. In fact, islets have never been free from all other pancreatic tissue making it difficult to specifically predict the characteristic of insulin-producing $\beta$ cells. Hence, we hypothesize that analysis of multiple biomolecules, instead of cellular ATP alone, would represent a more robust method to predict the status of human islets. In this study, we first developed a single step procedure for extracting total ATP, DNA, insulin, and protein content. Then, we established a simple, highly sensitive and effective method to measure total ATP content. Lastly, we applied multiple mathematical formulas to integrate values of total ATP, DNA, insulin, and protein content to assess islet status.

\section{Materials and methods}

Human islet isolation

Human cadaveric pancreata were obtained from local (California) or out-of-state organ procurement organizations. All pancreata used in this study were obtained with research consent from next-to-kin of donors, and the study was approved by the institutional review board of City of Hope. All islet isolations were carried out at a good manufacturing practice (GMP) facility at the City of Hope using standard operating procedures (Qi et al. 2015a). Tissue digestion was carried out using a modified semiautomatic method described previously (Qi et al. 2015a; Ricordi et al. 2016). Digested tissue was purified using a COBE 2991 cell processor (COBE laboratories Inc., Lakewood, CA, USA). The purification was conducted using a continuous gradient by loading $1.100 \mathrm{~g} / \mathrm{mL}$ and $1.077 \mathrm{~g} / \mathrm{mL}$ digested tissue $(\leq 40 \mathrm{~mL} / \mathrm{run})$ in cold $\left(4{ }^{\circ} \mathrm{C}\right)$ preservation solution. The purified tissue was collected into 7 fractions. Islet purity was assessed using dithizone (DTZ), and the fractions were pooled according to their purity and estimated tissue volume. The islets were washed and cultured immediately after the isolation process (Qi et al. 2015a). Islets were cultured in Connaught Medical Research Laboratories (CMRL)-1066 supplemented media ( $\mathrm{pH} 7.4)$ with $0.5 \%$ human serum albumin (Baxter Healthcare Corporation, Irvine, CA, USA) and $0.1 \mu \mathrm{g} / \mathrm{mL}$ insulin-like growth factor-1 (Cell Sciences, Canton, MA, USA). Islets that were $>80 \%$ pure and $>90 \%$ viable were used in this study. Human islets were counted using DTZ staining, and the islet equivalent (IEQ) number was extrapolated as described previously (Ricordi et al. 1990).

Extraction of total ATP, DNA, insulin, and protein content

Islet aliquots were washed twice with cold DPBS (MediaTech, Inc. Manassas, VA, USA) and centrifuged twice for $1 \mathrm{~min}$ at $100 \times g$ (Eppendorf Centrifuge 5415D, Eppendorf, Westbury, NY). At the end of centrifugation, supernatant was removed and $600 \mu \mathrm{L}$ of Somatic cell ATP releasing reagent (ARA) (Sigma-Aldrich, St. Louis, MO, USA) was added to the islet pellets before the samples were sonicated on ice for $1 \mathrm{~min}$ (Branson Sonifier 250, 
Danbury, CT). After sonication, $400 \mu \mathrm{L}$ of ARA was added to the sample, and the sample was centrifuged for $15 \mathrm{~min}$ at $1400 \times g\left(4^{\circ} \mathrm{C}\right)$. Lastly, $800 \mu \mathrm{L}$ of supernatant was collected for further measurement of total ATP, DNA, insulin, and protein content.

Evaluation of highly sensitive bioluminescent ATP assay

Total ATP content was quantified using an assay developed in our laboratory at City of Hope. ATP is hydrolyzed to AMP and pyrophosphate when luciferase catalyzes luciferin to oxyluciferin, during which light is produced and detected. Total ATP was associated to relative light units (RLU), which was measured using a Revelation MLX Version 4.06 Microtiter Plate Luminometer (Dynex Technologies, Inc., Chantilly, VA). The standard curve between ATP (Fisher BioReagents, Pittsburgh, PA) concentrations $(0,97,195,390,790,1563$, and $3125 \mathrm{nM})$ and RLU was established. An ATP standard curve was established for each assay performed using a single stock solution of 0.1 M ATP diluted in lysis buffer. Lysis buffer (1\% lecithin, $25 \mathrm{mM}$ Tris-PO4, 2\% CHAPS, $15 \%$ glycerol and $1 \%$ BSA) was filtered and stored at $4{ }^{\circ} \mathrm{C}$ until used. Briefly, $40 \mu \mathrm{L}$ of the standard or samples was loaded in duplicate in a 96-well plate (COSTAR 3915 FT bottom). Subsequently, $90 \mu \mathrm{L}$ of freshly prepared luciferase buffer $(3.2635 \mathrm{mM}$ magnesium sulfate, $24.339 \mathrm{mM}$ Tricine, $1.3054 \mathrm{mM}$ Magnesium carbonate, $0.122 \mathrm{mM}$ EDTA, $6.1 \mathrm{mM}$ DL-Dithiothreitol (DTT) (Sigma-Aldrich), $0.183 \mathrm{mg} /$ mL coenzyme A (Avanti Polar Lipids, Alabaster, Alabama), $0.611 \mathrm{mM}$ luciferin (D-Luciferin Firefly) (Photinus pyralis, Biosynth, Switzerland), and $0.11 \mathrm{ng} / \mathrm{mL}$ Luciferase (Roche Applied Science, Mannheim, Germany) was added. Luciferase was added to luciferase buffer immediately before reading the plate. As needed, the concentration of luciferase was increased five or tenfold to increase the sensitivity of the assay. Luminescence was read using a TECAN Magellan reader, and the standard curve was established. ATP concentrations of the measured samples were extrapolated from the ATP standard curve.

DNA content measurement

Total DNA content was measured using a Quant-iT PicoGreen dsDNA Assay kit (Invitrogen, Carlsbad,
CA, USA) following manufacturer instructions. DNA standards ranged from 10 to $1000 \mathrm{ng} / \mathrm{mL}$. Concentrated human islet samples were diluted in $1 \mathrm{X} \mathrm{TE}$ (Tris-EDTA). Samples and standards were plated in 96-black-well plates (Corning 3915, Corning Inc., Corning, NY) and read (excitation $485 \mathrm{~nm}$, emission $535 \mathrm{~nm}$ ) using a Tecan Magellan V 6.5 Genios (Tecan Systems, Inc., San Jose, CA). Sample concentrations were determined from the standard curve.

\section{Insulin content measurement}

Insulin ELISA kit (Mercodia, Uppsala, Sweden) was used to measure total insulin content following manufacturer instructions. Plates were read using the Tecan Magellan V 6.5 Genios at absorbance of $450 \mathrm{~nm}$. Sample concentrations were determined from the standard curve.

\section{Protein content measurement}

BCA Protein Assay Kit (Thermo Scientific Pierce, Rockford, IL, USA) was used to measure total protein content using the microplate procedure. 1X PBS (MediaTech, Inc., Manassas, VA) was used as the diluent for the standards and was also used to dilute concentrated samples $\geq 2000 \mu \mathrm{g} / \mathrm{mL}$, when necessary. Bovine serum albumin standards (BSA) ranged from 25 to $2000 \mu \mathrm{g} / \mathrm{mL}$ using the standard protocol. For samples with low protein content, BSA standards ranged from 5 to $250 \mu \mathrm{g} / \mathrm{mL}$, and the enhanced protocol was used. Samples and standards were plated in 96-well-clear plates (Corning 3590, Corning Inc.) and read by a Tecan Magellan V 6.5 Genios $(595 \mathrm{~nm}$ absorbance). The concentrations of measured samples were extrapolated from the standard curve using the slope-intercept form.

\section{Human islet assessment}

Human islets were cultured for $24-72 \mathrm{~h}$ before use. Aliquots of 100, 200, 400, and 800 IEQ human islets were used to study the correlation between different extraction conditions and total ATP, DNA, insulin, and protein content. Multiple mathematic formulas incorporating total ATP, DNA, insulin, and protein content were randomly tested using data obtained from different islet aliquots to verify the correlation effect. Furthermore, islets were compared under three 
conditions in terms of total ATP, DNA, insulin, protein content, as well as the calculated value using the optimized formula. The three conditions were: (1) ARA group $(n=10)$ : islets were directly exposed to ARA to extract ATP; (2) $37^{\circ} \mathrm{C}$ culture group $(n=4)$ : islets were cultured under normal culture condition in CMRL-1066 media at $37^{\circ} \mathrm{C} / 5 \% \mathrm{CO}_{2}$ for $12 \mathrm{~h}$; (3) $-80^{\circ} \mathrm{C}$ freezing group $(\mathrm{n}=4)$ : islets were snap frozen at $-80^{\circ} \mathrm{C}$ for $12 \mathrm{~h}$. At the end of experimental conditions $(2,3)$, islets were collected and washed twice with cold PBS before ARA was added. 200 IEQ islets were used in each condition and the three groups of islets were processed for extraction of total ATP, DNA, insulin, and protein content.

\section{Statistical analysis}

GraphPad Prism (GraphPad Software 6.0, La Jolla, CA, USA) was used to analyze data and generate figures. Linear regression analysis was used to determine the degree of correlation between the islet doses and total ATP, DNA, insulin, protein content, and formula calculated values. One-way analysis of variance (ANOVA) was used to compare among the three islet groups, followed by Tukey's multiple comparisons test to compare the mean values between any two groups. Values were expressed as mean \pm standard error of mean (SEM), $p<0.05$ was considered significant.

\section{Results and discussion}

Islet $\beta$ cells are metabolically active and ATP molecules are the source of energy for insulin synthesis and secretion (Henquin et al. 1985, 2006). When glucose is metabolized in $\beta$ cells, it leads to ATP production, which in turn closes ATP-dependent $\mathrm{K}^{+}$ channels, depolarizes the cell membrane, and opens voltage-dependent $\mathrm{Ca}^{2+}$ channels. The opening of $\mathrm{Ca}^{2+}$ channels triggers extracellular $\mathrm{Ca}^{2+}$ influx, causing insulin to be released from $\beta$ cells (Lumelsky et al. 2001; Felix-Martinez and Godinez-Fernandez 2014; Wills et al. 2016; Luciani et al. 2007). Therefore, assessing ATP alone without insulin is a poor predictor of islet function.

In this study, a single-step extraction of total cellular ATP, DNA, insulin, and protein content from human islet samples were evaluated. The extraction process is simple, fast, and can be adapted to any cell type. The biomolecules were quantified and the values were integrated into multiple simplified mathematical formulas to predict islet status. Initially, an ATP standard curve was established to measure total ATP content from islets (Fig. 1). The standard curve was highly correlated $\left(\mathrm{R}^{2}=0.9983, p<0.0001\right)$ between standard ATP concentrations and RLU readings $(\mathrm{n}=17)$.

After standardizing the ATP measurement, we measured total DNA, insulin, and protein. Figure 2a shows a close association between ATP concentrations and islet IEQ numbers $\left(\mathrm{R}^{2}=0.9830, p<0.01\right)$. Total DNA (Fig. $2 \mathrm{~b}, \mathrm{R}^{2}=0.9732, p<0.05$ ), insulin (Fig. 2c, $\mathrm{R}^{2}=0.9354, \quad p<0.05$ ), and protein (Fig. 2 d, $\mathrm{R}^{2}=0.8824, p<0.05$ ) were strongly correlated with an increasing IEQ number (Fig. 2b-d).

A total of 12 mathematic formulas were applied and tested randomly for evaluating the multiple cellular biomolecules described in different conditions and islet numbers (100, 200, 400, and 800 IEQ). Seven relevant formulas were listed (Fig. 3):

ATP/DNA/Insulin $\times$ Protein

ATP $/$ DNA $\times$ Insulin/Protein

ATP $/$ DNA $/ \log ($ Insulin $) / \log ($ Protein $)$

ATP $/$ DNA $\times \log ($ Insulin $) / \log ($ Protein $)$

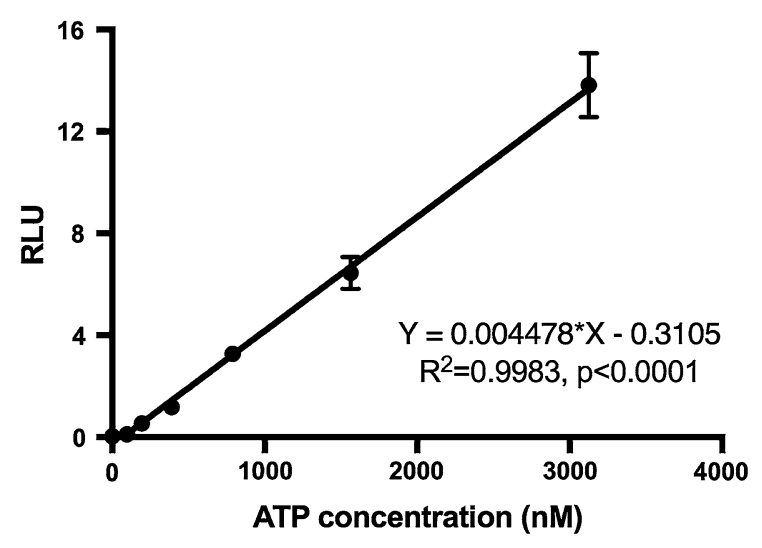

Fig. 1 ATP standard curve. The data shows the high correlation $\left(\mathrm{R}^{2}=0.9983, p<0.0001\right)$ between standard ATP samples $(0,97,195,390,790,1563$, and $3125 \mathrm{nM})$ and the RLU reading $(\mathrm{n}=17)$ 
Fig. 2 Total ATP, DNA, insulin, and protein contents from different human islets. Measured total ATP, DNA, insulin, and protein contents correlated well with IEQ (100 IEQ, $\mathrm{n}=2 ; 200$ IEQ, $\mathrm{n}=13 ; 400$ IEQ, $\mathrm{n}=10$; and 800 IEQ, $\mathrm{n}=6$ ). ATP: $\mathrm{R}^{2}=0.9830$, $p<0.01$ (a). DNA: $\mathrm{R}^{2}=0.9732, p<0.05$ (b). Insulin: $\mathrm{R}^{2}=0.9354$, $p<0.05$ (c). Protein: $\mathrm{R}^{2}=0.8824, p<0.05(\mathbf{d})$
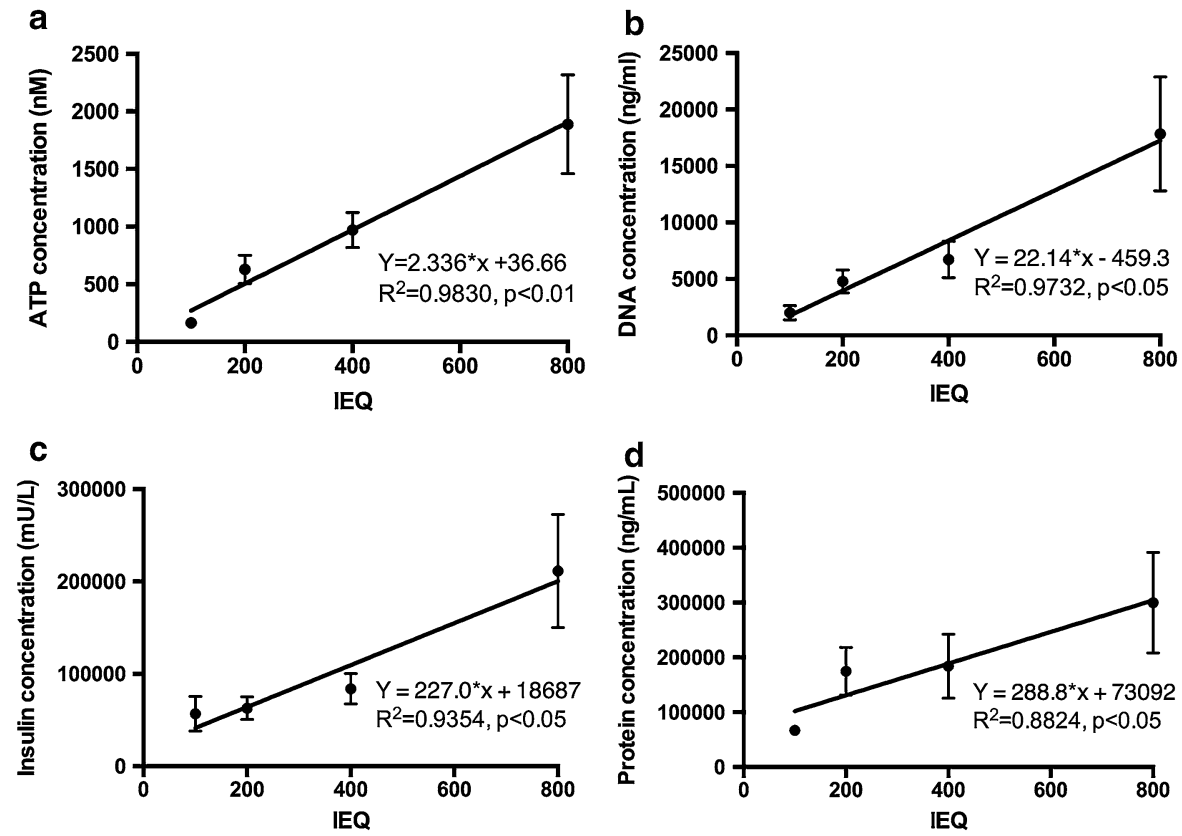

$\log ($ ATP $) / \log ($ DNA $) / \log ($ Insulin $) \times \log ($ Protein $)$

$\log ($ ATP $) / \log ($ DNA $) \times \log ($ Insulin $) / \log ($ Protein $)$

$\log ($ ATP $) / \log ($ DNA $) \times \log ($ Insulin $\times$ Protein $)$

Serendipitously, Formula 7 was found to be the most accurate equation verifying the correlation between the 4 biomarkers under different biological conditions tested (Fig. 3g, $\mathrm{R}^{2}=0.9674, p=0.016$ ).

Furthermore, we measured total ATP, DNA, insulin, and protein content of human islets under different storage and culture conditions (Fig. 4a-d). The ATP content measured from frozen islets was $0.10 \mathrm{nM}$ (the minimal detectable value using this method), which was significantly lower than ATP content measured from both ATP releasing agent (ARA) $(458.30 \pm 53.91 \mathrm{nM}, p<0.0001)$ and $37^{\circ} \mathrm{C}$ culture $(337.40 \pm 45.06 \mathrm{nM}, \quad p<0.001)$ groups. With regard to total DNA, insulin, and protein levels, we observed no significant differences between frozen islet group and either the ARA or $37^{\circ} \mathrm{C}$ culture groups. Therefore, Formula 7 was used to evaluate the characteristic of the islets under different conditions (Fig. 4e). The calculated value of the $-80^{\circ} \mathrm{C}$ freezing group $(-3.10 \pm 0.17)$ was significantly lower than that of both the ARA $(8.13 \pm 0.43, p<0.0001)$ and $37^{\circ} \mathrm{C}$ culture $(7.65 \pm 0.37, p<0.0001)$ groups.

The results of our current study reveal several advantages over current practices:

First, our assessment requires only a single ATP releasing agent to simultaneously extract total ATP, DNA, insulin, and protein content. A previous study showed that ATP could be extracted from living cells using boiling water (Yang et al. 2002). However, variability of extracellular ATP content has been reported, and previous work did not account for DNA, insulin, and protein content (Brandhorst et al. 1999). In this study, we found no difference in calculated ATP, DNA, insulin, and protein content between the ARA and $37^{\circ} \mathrm{C}$ culture groups, suggesting that our test can be performed immediately after islet isolation. Notably, the ATP level of islets directly exposed to ARA was similar to that of islets after culture, which indicates that the ATP extracting reagent released ATP efficiently and without damaging the ATP molecules.

Second, together with DNA, insulin, and protein, the ATP content could provide comprehensive characteristic of islets represented by a simple mathematical formulation. Previous study reported that ATP and protein levels measured to predict islet transplantation outcome in a pig-to-mouse transplant model (Kim et al. 2009). The intra-islet ATP content was 
Fig. 3 Mathematical formulations integrating total ATP, DNA, insulin, and protein. Seven different mathematical formulations were used to assess human islets using different IEQs: $100(n=2), 200(n=13)$, $400(\mathrm{n}=10)$, and 800 IEQ $(\mathrm{n}=6)$. Only Formula 7 displayed strong correlation between the calculated values and different number of islets (Fig. 3g, $\left.\mathrm{R}^{2}=0.9674, p=0.016\right)$. This formula was found to be the best mathematical equation to assess human islets because it integrated all measured parameters: ATP, DNA, insulin and protein a

Formula 1: ATP/DNA/Insulin $\times$ Protein

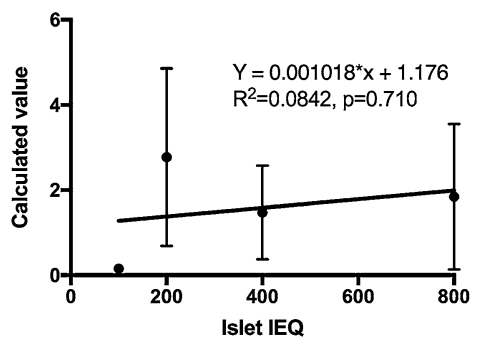

C

Formula 3: ATP/DNA/Log (Insulin)/Log (Protein)

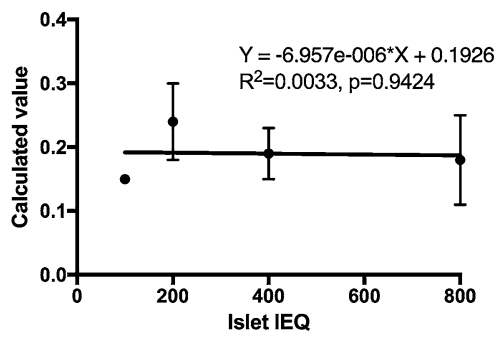

e

Formula 5:

$\log ($ ATP)/Log (DNA)/Log (Insulin) $\times$ Log (Protein)

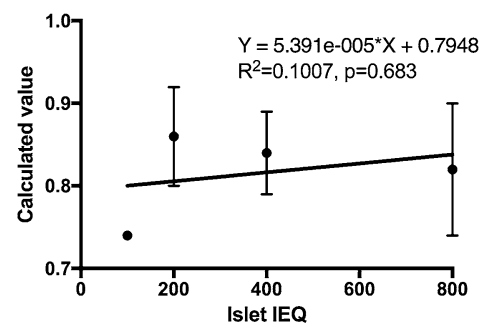

g Formula 7:
$\log ($ ATP $) / \log ($ DNA $) \times \log ($ Insulin $\times$ Protein $)$

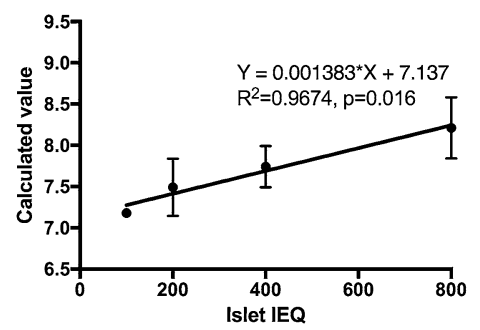

b

Formula 2: ATP/DNA $\times$ Insulin/Protein

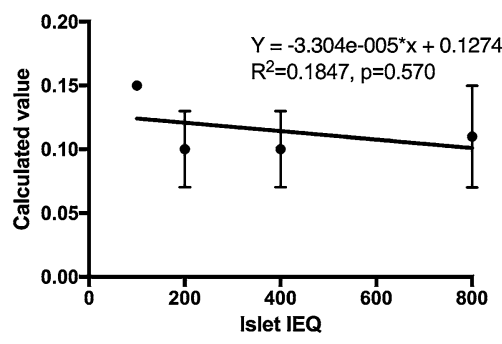

d

Formula 4:

ATP/DNA $\times$ Log (Insulin)/Log (Protein)

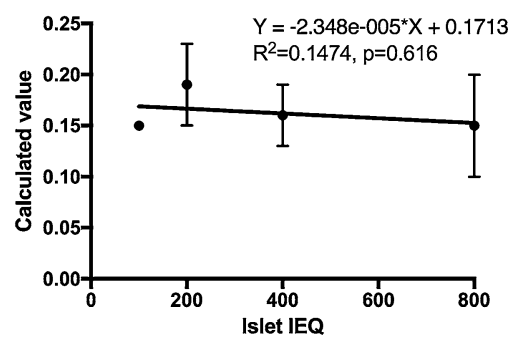

f

Formula 6:

$\log ($ ATP)/Log (DNA) $\times$ Log (Insulin)/Log (Protein)

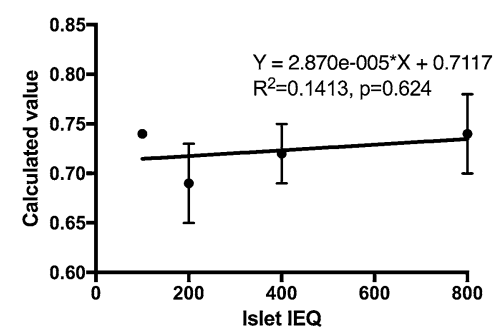

normalized using the porcine islet protein level. However, handpicked islets (100-150 $\mu \mathrm{m}$ in size) were used in the experiment, which does not truly represent islet samples in the clinical setting and therefore limited its application. Several studies used the ADP/ATP or ATP/ADP ratio to predict islet quality, but the results remain controversial (Goto et al. 2006; Sweet et al. 2004). This is partially due to the rapid depletion of ATP and ADP in dead cells; this can lead to high or low ADP/ATP ratios that do not accurately reflect the biological condition of islets. In fact, one study suggested using the combination of ADP/ATP and islet tissue factor measurements as a test for islet potency (Goto et al. 2006). In another 

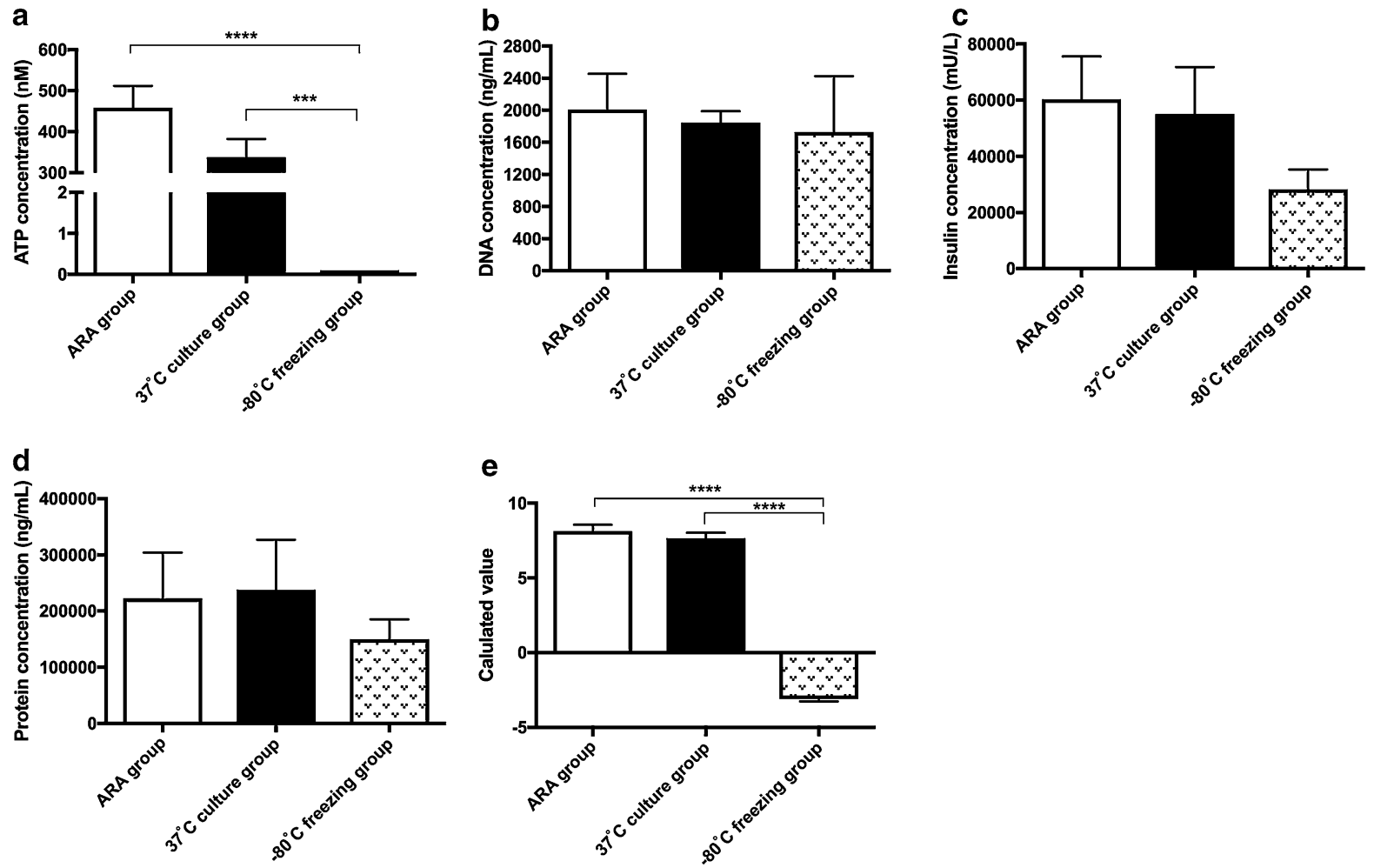

Fig. 4 The measured ATP, DNA, insulin, protein, and calculated value of Formula 7 for human islets in ARA, $37^{\circ} \mathrm{C}$ culture, and $-80^{\circ} \mathrm{C}$ freezing groups. ATP level of frozen islets was $0.10 \pm 0.00 \mathrm{nM}$ (the minimal detectable value using this method), which was significantly lower than that of both ARA $(458.30 \pm 53.91 \mathrm{nM}, * * * * p<0.0001)$ and $37^{\circ} \mathrm{C}$ culture

report, ATP/DNA, rather than ADP/ATP ratio, was claimed to be a superior indictor of islet viability (Suszynski et al. 2008). Our study improves on the prior literature by integrating not only ATP and DNA content, but also insulin and protein content into a single mathematical calculation. Islet preparation has never been free from acinar tissue and therefore DNA content per se would not indicate specificity to the islet. Therefore, using insulin and total protein, in addition to total ATP and DNA, is of paramount importance to assess insulin-producing $\beta$ cells (Formula 7).

Lastly, it is well understood that cells cease energy production under freezing conditions (Graumann and Marahiel 1996; Amato and Christner 2009). This was clearly demonstrated in the current study where islets undergoing freezing at $-80^{\circ} \mathrm{C}$ had undetectable levels of ATP content, reflecting the static metabolic condition of the cells. In contrast, islets processed $\left(337.40 \pm 45.06 \mathrm{nM},{ }^{* * *} p<0.001\right)$ groups (a). No significant differences were found for total DNA, insulin, and protein $(\mathbf{b}, \mathbf{c}$, d). The Formula 7 calculated value of the $-80^{\circ} \mathrm{C}$ freezing group $(-3.10 \pm 0.17)$ was significantly lower than that of both ARA $(8.13 \pm 0.43, * * * * p<0.0001)$ and $37^{\circ} \mathrm{C}$ culture $(7.65 \pm 0.37$, $* * * * p<0.0001)$ groups $(\mathbf{e})$

immediately after culture or directly exposed to ARA showed noticeably higher ATP content. These differences were predicted by our mathematical formula (Formula 7) that accurately yielded assessments of different islet characteristics; this suggests that Formula 7 might help unravel the effect of secretagogues to stimulate islets for ATP and insulin upregulation and secretion.

In conclusion, total ATP, DNA, insulin, and protein content can be extracted from human islets using a single step procedure and further quantified. When all the data is integrated into a simple logarithmic formulation, it can predict islet status at different conditions.

Acknowledgements This work was supported by a grant from the National Institute of Health (NIH), the Southern California Islet Cell Resources Center (SC-ICR) 5U42RR016607 and the City of Hope. We thank all members of the islet isolation team for preparing human islets. We thank Dr. Barry Forman for 
sharing resources and advices. We also thank Amber Tucker, Henry Lin, Leonard Chen, and Chris Gandhi for providing comments to the manuscript. This paper is subject to the NIH Public Access Policy.

\section{Compliance with ethical standards}

Conflict of interest The authors declare that there are no conflicts of interest.

Open Access This article is distributed under the terms of the Creative Commons Attribution 4.0 International License (http:// creativecommons.org/licenses/by/4.0/), which permits unrestricted use, distribution, and reproduction in any medium, provided you give appropriate credit to the original author(s) and the source, provide a link to the Creative Commons license, and indicate if changes were made.

\section{References}

Amato P, Christner BC (2009) Energy metabolism response to low-temperature and frozen conditions in Psychrobacter cryohalolentis. Appl Environ Microbiol 75(3):711-718

Bonner-Weir S, Sullivan BA, Weir GC (2015) Human islet morphology revisited: human and rodent islets are not so different after all. J Histochem Cytochem 63(8):604-612

Brandhorst D, Brandhorst H, Hering BJ, Federlin K, Bretzel RG (1999) Large variability of the intracellular ATP content of human islets isolated from different donors. J Mol Med 77(1):93-95

Buchwald P, Bernal A, Echeverri F, Tamayo-Garcia A, Linetsky E, Ricordi C (2016) Fully automated islet cell counter (ICC) for the assessment of islet mass, purity, and size distribution by digital image analysis. Cell Transpl 25:1747-1761

Chida J, Yamane K, Takei T, Kido H (2012) An efficient extraction method for quantitation of adenosine triphosphate in mammalian tissues and cells. Anal Chim Acta 727:8-12

Cox DJ, Irvine A, Gonder-Frederick L, Nowacek G, Butterfield J (1987) Fear of hypoglycemia: quantification, validation, and utilization. Diabetes Care 10(5):617-621

Felix-Martinez GJ, Godinez-Fernandez JR (2014) Mathematical models of electrical activity of the pancreatic beta-cell: a physiological review. Islets 6(3):e949195

Goto M, Holgersson J, Kumagai-Braesch M, Korsgren O (2006) The ADP/ATP ratio: a novel predictive assay for quality assessment of isolated pancreatic islets. Am J Transpl 6(10):2483-2487

Graumann P, Marahiel MA (1996) Some like it cold: response of microorganisms to cold shock. Arch Microbiol 166(5):293-300

Henquin JC, Schmeer W, Nenquin M, Meissner HP (1985) Effects of a calcium channel agonist on the electrical, ionic and secretory events in mouse pancreatic B-cells. Biochem Biophys Res Commun 131(2):980-986

Henquin JC, Nenquin M, Stiernet P, Ahren B (2006) In vivo and in vitro glucose-induced biphasic insulin secretion in the mouse: pattern and role of cytoplasmic $\mathrm{Ca}^{2+}$ and amplification signals in beta-cells. Diabetes 55(2):441-451

Hering BJ, Clarke WR, Bridges ND, Eggerman TL, Alejandro R, Bellin MD, Chaloner K, Czarniecki CW, Goldstein JS, Hunsicker LG, Kaufman DB, Korsgren O, Larsen CP, Luo X, Markmann JF, Naji A, Oberholzer J, Posselt AM, Rickels MR, Ricordi C, Robien MA, Senior PA, Shapiro AM, Stock PG, Turgeon NA, Clinical Islet Transplantation C (2016) Phase 3 trial of transplantation of human islets in type 1 diabetes complicated by severe hypoglycemia. Diabetes Care 39(7):1230-1240

Kim JH, Park SG, Lee HN, Lee YY, Park HS, Kim HI, Yu JE, Kim SH, Park CG, Ha J, Kim SJ, Park KS (2009) ATP measurement predicts porcine islet transplantation outcome in nude mice. Transplantation 87(2):166-169

Kracht MJ, van Lummel M, Nikolic T, Joosten AM, Laban S, van der Slik AR, van Veelen PA, Carlotti F, de Koning EJ, Hoeben RC, Zaldumbide A, Roep BO (2017) Autoimmunity against a defective ribosomal insulin gene product in type 1 diabetes. Nat Med 23(4):501-507

Lacy PE (1967) The pancreatic beta cell: structure and function. N Engl J Med 276(4):187-195

Larsson C, Pahlman IL, Gustafsson L (2000) The importance of ATP as a regulator of glycolytic flux in Saccharomyces cerevisiae. Yeast 16(9):797-809

Luciani DS, Ao P, Hu X, Warnock GL, Johnson JD (2007) Voltage-gated $\mathrm{Ca}(2+)$ influx and insulin secretion in human and mouse beta-cells are impaired by the mitochondrial $\mathrm{Na}(+) / \mathrm{Ca}(2+)$ exchange inhibitor CGP-37157. Eur J Pharmacol 576(1-3):18-25

Lumelsky N, Blondel O, Laeng P, Velasco I, Ravin R, McKay R (2001) Differentiation of embryonic stem cells to insulinsecreting structures similar to pancreatic islets. Science 292(5520):1389-1394

Manfredi G, Yang LC, Gajewski CD, Mattiazzi M (2002) Measurements of ATP in mammalian cells. Methods 26(4):317-326

Papas KK, Suszynski TM, Colton CK (2009) Islet assessment for transplantation. Curr Opin Organ Transpl 14(6):674-682

Phillippy BQ (1994) Reliable luminescent detection of subpicomole amounts of ATP using a scintillation counter. Biotechniques 16(4):596-598

Qi M, Valiente L, McFadden B, Omori K, Bilbao S, Juan J, Rawson J, Scott S, Ferreri K, Mullen Y, El-Shahawy M, Dafoe D, Kandeel F, Al-Abdullah IH (2015a) The choice of enzyme for human pancreas digestion is a critical factor for increasing the success of islet isolation. Transpl Direct 1(4):1-9

Qi M, McFadden B, Valiente L, Omori K, Bilbao S, Juan J, Rawson J, Oancea AR, Scott S, Nair I, Ferreri K, Mullen Y, Dafoe D, Ei-Shahawy M, Kandeel F, Al-Abdullah IH (2015) Human pancreatic islets isolated from donors with elevated HbA1c levels: islet yield and graft efficacy. Cell Transpl 24(9):1879-1886

Ricordi C, Gray DW, Hering BJ, Kaufman DB, Warnock GL, Kneteman NM, Lake SP, London NJ, Socci C, Alejandro R et al (1990) Islet isolation assessment in man and large animals. Acta Diabetol Lat 27(3):185-195

Ricordi C, Goldstein JS, Balamurugan AN, Szot GL, Kin T, Liu C, Czarniecki CW, Barbaro B, Bridges ND, Cano J, Clarke 
WR, Eggerman TL, Hunsicker LG, Kaufman DB, Khan A, Lafontant DE, Linetsky E, Luo X, Markmann JF, Naji A, Korsgren O, Oberholzer J, Turgeon NA, Brandhorst D, Friberg AS, Lei J, Wang LJ, Wilhelm JJ, Willits J, Zhang X, Hering BJ, Posselt AM, Stock PG, Shapiro AM (2016) National institutes of health-sponsored clinical islet transplantation consortium phase 3 trial: manufacture of a complex cellular product at eight processing facilities. Diabetes 65(11):3418-3428

Shepherd RD, Rinker KD (2004) Bioluminescence-based ATP assays using a charge-coupled device imaging system. Biotechniques 37(2):208-210

Shepherd RK, Checcarelli N, Naini A, De Vivo DC, DiMauro S, Sue CM (2006) Measurement of ATP production in mitochondrial disorders. J Inherit Metab Dis 29(1):86-91

Suszynski TM, Wildey GM, Falde EJ, Cline GW, Maynard KS, Ko N, Sotiris J, Naji A, Hering BJ, Papas KK (2008) The ATP/DNA ratio is a better indicator of islet cell viability than the ADP/ATP ratio. Transpl Proc 40(2):346-350

Sweet IR, Cook DL, DeJulio E, Wallen AR, Khalil G, Callis J, Reems J (2004) Regulation of ATP/ADP in pancreatic islets. Diabetes 53(2):401-409
Sweet IR, Gilbert M, Jensen R, Sabek O, Fraga DW, Gaber AO, Reems J (2005) Glucose stimulation of cytochrome C reduction and oxygen consumption as assessment of human islet quality. Transplantation 80(8):1003-1011

Wang Z, Xie Z, Lu Q, Chang C, Zhou Z (2017) Beyond genetics: what causes type 1 diabetes. Clin Rev Allergy Immunol 52(2):273-286

Wills QF, Boothe T, Asadi A, Ao Z, Warnock GL, Kieffer TJ, Johnson JD (2016) Statistical approaches and software for clustering islet cell functional heterogeneity. Islets $8(2): 48-56$

Yang NC, Ho WM, Chen YH, Hu ML (2002) A convenient onestep extraction of cellular ATP using boiling water for the luciferin-luciferase assay of ATP. Anal Biochem 306(2):323-327

Zhou J, Liu L, Shi Z, Du G, Chen J (2009) ATP in current biotechnology: regulation, applications and perspectives. Biotechnol Adv 27(1):94-101

Zimmermann H (2016) Extracellular ATP and other nucleotides-ubiquitous triggers of intercellular messenger release. Purinergic Signal 12(1):25-57 